\title{
Lupus erythematosus cell phenomenon in patients with chronic ulcerative colitis ${ }^{1}$
}

\author{
DONATO ALARCÓN-SEGOVIA, TEODORO HERSKOVIC, \\ WILLIAM H. DEARING, LLOYD G. BARTHOLOMEW, \\ JAMES C. CAIN, AND ROY G. SHORTER
}

From the Mayo Clinic and Mayo Foundation, Rochester, Minnesota, U.S.A.

EDITORIAL SYNOPSIS The interesting suggestion is put forward that sulphonamides may unmask a latent lupus diathesis in some patients with ulcerative colitis.

Present knowledge of systemic lupus erythematosus, albeit scarce, has been accumulated slowly since its original description to its present recognition as a complex systemic disease responsible for a number of syndromes previously considered unrelated. The true incidence of systemic lupus erythematosus, though still unknown, evidently is much greater than was realized before the discovery of the L.E. cell phenomenon by Hargraves, Richmond, and Morton (1948). From their finding has stemmed also the concept that autoimmune mechanisms operate in systemic lupus erythematosus and probably are responsible for at least some of its clinical and laboratory manifestations.

Little also is known of the pathogenesis of chronic ulcerative colitis. Studies on the role of immunity in that condition have been inconclusive (Good and Condie, 1961; Kraft, Bregman, and Kirsner, 1962) but extracolonic manifestations are being recognized with increasing frequency (Sloan, Bargen, and Gage, 1950; Hightower, Broders, Haines, McKenney, and Sommer, 1958). Particularly interesting are the associated arthritis and the hepatic damage.

We have found 11 cases of systemic lupus erythematosus associated with chronic ulcerative colitis reported in the literature (Brown, Haserick, and Shirey, 1956a; Gray, Mackay, Taft, Weiden, and Wood, 1958; Bartholomew, Hagedorn, Cain, and Baggenstoss, 1958; Larson, 1961 ; McEwen, Lingg, Kirsner, and Spencer, 1962). Although the paucity of these reports may indicate that this association is merely coincidental, the systemic manifestations of both diseases and some peculiarities of the cases reported may indicate that the association is of some significance.

During the year 1962, 475 patients with chronic

${ }^{1}$ This investigation was supported in part by research grant AM-06908 from the National Institutes of Health, Public Health Service. ulcerative colitis were seen at the Mayo Clinic. These included 252 females ( 3 to 77 years of age) and 223 males ( 1 to 78 years of age). One hundred of these patients had one or more tests for L.E. cells performed by the method of Zimmer and Hargraves (1952) and Hargraves (1954). The tests were positive in three patients, all females (cases 4, 5, and 6 of our series). These three patients not only had symptoms of unequivocal chronic ulcerative colitis but also demonstrated evidence of many systemic symptoms and tests for L.E. cells in the peripheral blood were repeatedly positive. Two of these three patients showed clinical and laboratory data of hepatic dysfunction.

In 97 ( 52 males and 45 females) of the 100 patients with chronic ulcerative colitis in whom an L.E. test was performed, no L.E. cells were found. The L.E. tests were performed for a number of reasons, including abnormal laboratory findings, extracolonic symptoms, and as a matter of routine by some consultants. None of these 97 patients had sufficient clinical or laboratory findings to warrant the diagnosis of systemic lupus erythematosus. On the other hand, 24 (15 males and nine females) of these 97 patients $(24.7 \%)$ had both clinical and laboratory evidence of significant liver disease.

An L.E. cell test was not performed in $\mathbf{3 7 5}$ of the patients with chronic ulcerative colitis seen in 1962, but clinical findings in 162 of them seemed to warrant further evaluation of liver function. Laboratory evidence of significant liver disease was found in 38 ( 11 females and 27 males) of these 162 patients $(23.5 \%)$. This incidence of hepatic disease was essentially the same as in the group of 97 patients in whom L.E. cells were sought but not found. As will be seen later, this is in direct contrast to the smaller group with demonstrable L.E. cells. 
To study the significance of these findings, namely, the association of chronic ulcerative colitis, a positive test for L.E. cells, and symptoms suggesting systemic lupus erythematosus, the records of all patients who had chronic ulcerative colitis and a positive L.E. test were reviewed. Eight patients with these specifications were found who had been seen at the Mayo Clinic since Hargraves et al. (1948) discovered the L.E. cell phenomenon in 1948.

\section{REPORT OF CASES}

CASE 1 A 20-year-old man when first seen in 1943 gave a history of loose, bloody stools for five years. The diagnosis of chronic ulcerative colitis had been established elsewhere, but symptoms had not been controlled. Six months before examination at the Mayo Clinic, the stools had increased to eight to 10 per day with urgency and accompanying cramping pain. The family history, review of systems, and physical examination were negative. On proctoscopic examination the intestinal mucosa was granular and bled easily. Radiological study of the colon revealed typical findings of chronic ulcerative colitis. Treatment was begun with succinylsulphathiazole (Sulphasuxidine, 4 to $6 \mathrm{~g}$. per day) which he continued intermittently for an unknown period.

The patient was seen again in 1955. In the interval he had experienced remissions and relapses in his disease. In October 1954, while he was taking sulphamerazine (6 g. per day) and phthalylsulphathiazole (Sulphathalidine, 2 to $3 \mathrm{~g}$. per day), fever, weakness, pleural pain, arthralgia of feet, hands, and shoulders, and loss of weight developed. Physical examination revealed left pleural effusion and pain on moving the joints. Proctoscopic examination showed scarring of the sigmoid and rectum but no evidence of active colitis. Two tests for L.E. cells were positive. Other pertinent laboratory data may be seen in Table I. Treatment with salicylazosulphapyridine (synonym: azopyrin, Azulfidine, Table II) was followed by worsening of symptoms. Use of this drug was discontinued and treatment with prednisone was started. Three months later the patient was asymptomatic while taking small doses of prednisone. He died elsewhere in 1959.

CASE 2 A 42-year-old man presented at the Mayo Clinic in 1937 with a history of bouts of bloody diarrhoea

TABLE I

LABORATORY DATA IN EIGHT CASES OF CHRONIC ULCERATIVE COLITIS AND SYSTEMIC LUPUS ERYTHEMATOSUS

\begin{tabular}{|c|c|c|c|c|c|c|c|c|c|c|c|c|c|}
\hline \multirow[t]{3}{*}{$\begin{array}{l}\text { Case } \\
\text { No. }\end{array}$} & \multirow[t]{3}{*}{ Date Seen } & \multirow{3}{*}{$\begin{array}{l}\text { Age } \\
(\text { (yr.) } \\
\text { and } \\
\text { Sex }\end{array}$} & \multirow{3}{*}{$\begin{array}{l}\text { Duration } \\
\text { of } \\
\text { Chronic } \\
\text { Ulcer- } \\
\text { ative } \\
\text { Colitis } \\
(y r .)\end{array}$} & \multirow[t]{3}{*}{$\begin{array}{l}\text { Haemoglobin } \\
(\mathrm{g} .1100 \mathrm{ml} .)\end{array}$} & \multirow[t]{3}{*}{$\begin{array}{l}\text { Leucocytes } \\
\text { (c.mm.) }\end{array}$} & \multirow{3}{*}{$\begin{array}{l}\text { Sediment- } \\
\text { ation Rate } \\
(\mathrm{mm} . \text { in } \\
1 \mathrm{hr} .)\end{array}$} & \multirow[t]{3}{*}{$\begin{array}{l}\text { L.E. } \\
\text { Cells }\end{array}$} & \multicolumn{3}{|c|}{$\begin{array}{l}\text { Serum Proteins } \\
(\mathrm{g} .1100 \mathrm{ml} .)\end{array}$} & \multirow{3}{*}{$\begin{array}{l}\text { Brom- } \\
\text { sulphalein } \\
\text { (\% } \% \text { in hr) }\end{array}$} & \multirow{3}{*}{$\begin{array}{l}\text { Total } \\
\text { Bilirubin } \\
\text { (mg./100 ml.) }\end{array}$} & \multirow{3}{*}{$\begin{array}{l}\text { Alkaline } \\
\text { Phosphatase } \\
\text { (K.-A.units } \\
100 \text { ml.) }\end{array}$} \\
\hline & & & & & & & & \multirow[t]{2}{*}{ Albumin } & \multicolumn{2}{|c|}{ Globulin } & & & \\
\hline & & & & & & & & & Total & Gamma & & & \\
\hline 1 & $\begin{array}{l}\text { Nov. } 1943 \\
\text { Mar. } 1955\end{array}$ & $20 \mathrm{M}$ & $\begin{array}{r}5 \\
18\end{array}$ & $\begin{array}{r}13 \cdot 1 \\
9 \cdot 3\end{array}$ & $\begin{array}{r}11,000 \\
6,000\end{array}$ & 22 & + & 3.6 & 4.0 & & & & \\
\hline \multirow[t]{3}{*}{2} & Dec. 1937 & $42 \mathrm{M}$ & 10 & 16.0 & 7,400 & & + & 300 & 4.0 & & & & \\
\hline & $\begin{array}{l}\text { July } 1955 \\
\text { Feb. } 1956\end{array}$ & $\begin{array}{l}59 \\
60\end{array}$ & $\begin{array}{l}28 \\
29\end{array}$ & $\begin{array}{l}9.7 \\
9.3\end{array}$ & $\begin{array}{l}4,500 \\
2,200\end{array}$ & $\begin{array}{l}102 \\
110\end{array}$ & + & $\begin{array}{l}2.9 \\
3.5\end{array}$ & $\begin{array}{l}3 \cdot 1 \\
2 \cdot 8\end{array}$ & & & & \\
\hline & Mar. 1963 & 67 & 36 & $13 \cdot 1$ & 7,600 & 98 & + & $3 \cdot 1$ & 3.0 & $1 \cdot 1$ & 40 & 0.60 & 72 \\
\hline \multirow[t]{2}{*}{3} & $\begin{array}{l}\text { Nov. } 1937 \\
\text { Aug. } 1938\end{array}$ & $\begin{array}{l}34 \mathrm{~F} \\
35\end{array}$ & $\begin{array}{l}5 \\
6\end{array}$ & $\begin{array}{l}12 \cdot 7 \\
12 \cdot 3\end{array}$ & $\begin{array}{r}8,600 \\
10,100\end{array}$ & 46 & & & & & & & \\
\hline & $\begin{array}{l}\text { July } 1955 \\
\text { Sept. } 1960\end{array}$ & $\begin{array}{l}52 \\
57\end{array}$ & $\begin{array}{l}23 \\
28\end{array}$ & $\begin{array}{l}12.4 \\
13.0\end{array}$ & $\begin{array}{l}7,200 \\
4,900\end{array}$ & $\begin{array}{l}55 \\
45\end{array}$ & \pm & 3.6 & $2 \cdot 8$ & & & & \\
\hline \multirow[t]{2}{*}{4} & $\begin{array}{l}\text { Sept. } 1960 \\
\text { Oct. } 1961\end{array}$ & $62 \mathrm{~F}$ & $2 \frac{1}{2}$ & $\begin{array}{r}9.6 \\
7 \cdot 5\end{array}$ & $\begin{array}{l}6,800 \\
4,100\end{array}$ & 77 & $\bar{t}$ & 2.5 & 3.5 & 1.5 & $\begin{array}{l}22 \\
40\end{array}$ & $\begin{array}{l}0.60 \\
3.8\end{array}$ & $90 \cdot 2$ \\
\hline & Mar. 1962 & 64 & 4 & $10 \cdot 1$ & 10,500 & & + & $2 \cdot 3$ & $2 \cdot 9$ & $1 \cdot 3$ & 38 & 3.6 & 74.4 \\
\hline 5 & $\begin{array}{l}\text { July } 1951 \\
\text { Jan. } 1959\end{array}$ & $\begin{array}{l}58 \mathrm{~F} \\
65\end{array}$ & $\begin{array}{l}1 \\
8 \frac{1}{2}\end{array}$ & $\begin{array}{l}11 \cdot 4 \\
10 \cdot 3\end{array}$ & $\begin{array}{l}3,700 \\
6,100\end{array}$ & $\begin{array}{l}48 \\
65\end{array}$ & + & & & & & & \\
\hline \multirow[t]{2}{*}{6} & $\begin{array}{l}\text { Aug. } 1963 \\
\text { Sept. } 1955\end{array}$ & $\begin{array}{l}70 \\
11 \mathrm{~F}\end{array}$ & $\begin{array}{c}13 \\
14\end{array}$ & $\begin{array}{l}\text { N.D. } \\
12.4\end{array}$ & $\begin{array}{l}3,800 \\
5,400\end{array}$ & $\begin{array}{l}35 \\
53\end{array}$ & \pm & 3.5 & $2 \cdot 9$ & 1.2 & 0 & 0.46 & 4.8 \\
\hline & $\begin{array}{l}\text { April } 1962 \\
\text { Dec. } 1962 \\
\text { Sept. } 1963\end{array}$ & $\begin{array}{l}17 \\
18 \\
19\end{array}$ & $\begin{array}{l}74 \\
7 \frac{1}{1} \\
8 \frac{1}{2} \\
91\end{array}$ & $\begin{array}{l}12.8 \\
13.0 \\
12 \cdot 3\end{array}$ & $\begin{array}{l}5,200 \\
7,000 \\
5,200\end{array}$ & $\begin{array}{l}63 \\
32 \\
47\end{array}$ & $\frac{+}{t}$ & $\begin{array}{l}2 \cdot 9 \\
2 \cdot 8 \\
2 \cdot 6\end{array}$ & $\begin{array}{l}5.1 \\
5.9 \\
2.7\end{array}$ & $\begin{array}{l}3 \cdot 0 \\
3 \cdot 4 \\
5 \cdot 3\end{array}$ & $\begin{array}{l}22 \\
18\end{array}$ & $\begin{array}{l}2.8 \\
0.7 \\
0.52\end{array}$ & $\begin{array}{l}51.0 \\
81.8 \\
60.0\end{array}$ \\
\hline \multirow[t]{2}{*}{7} & Aug. 1957 & $11 \mathrm{~F}$ & 0 & $\begin{array}{l}12.3 \\
11.8\end{array}$ & 5,000 & 47 & \pm & $2 \cdot 6$ & 2.7 & $5 \cdot 3$ & 18 & 0.32 & $00 \cdot 0$ \\
\hline & $\begin{array}{l}\text { May } 1961 \\
\text { Aug. } 1961\end{array}$ & & $\begin{array}{l}8 \mathrm{mth} . \\
11 \mathrm{mth} .\end{array}$ & $\begin{array}{r}9 \cdot 9 \\
12.8\end{array}$ & 15,400 & 101 & \pm & $\begin{array}{l}1 \cdot 80 \\
3 \cdot 30\end{array}$ & $\begin{array}{l}6.5 \\
5.5\end{array}$ & $\begin{array}{l}4 \cdot 1 \\
2 \cdot 8\end{array}$ & $\begin{array}{l}40 \\
24\end{array}$ & $\begin{array}{l}2 \cdot 6 \\
2 \cdot 38\end{array}$ & $22 \cdot 3$ \\
\hline \multirow[t]{3}{*}{8} & April1943 & $9 \mathrm{~F}$ & $\begin{array}{l}\text { Onset of } \\
\text { diarrhoea }\end{array}$ & $9 \cdot 8$ & 10,900 & 135 & + & 3.0 & 9.0 & & 0 & 0.1 & \\
\hline & July 1944 & 10 & $\begin{array}{l}\text { Con- } \\
\text { tinued } \\
\text { diarrhoea }\end{array}$ & $8 \cdot 4$ & 4,200 & 134 & & & & & & & \\
\hline & Dec. 1954 & 20 & $\begin{array}{l}\text { First } \\
\text { diagnosis } \\
\text { chronic } \\
\text { ulcerative } \\
\text { colitis }\end{array}$ & $4 \cdot 8$ & 7,200 & 145 & + & 1.47 & $9 \cdot 9$ & $8 \cdot 43$ & 22 & $1 \cdot 1$ & \\
\hline
\end{tabular}


TABLE II

TREATMENT AND COURSE

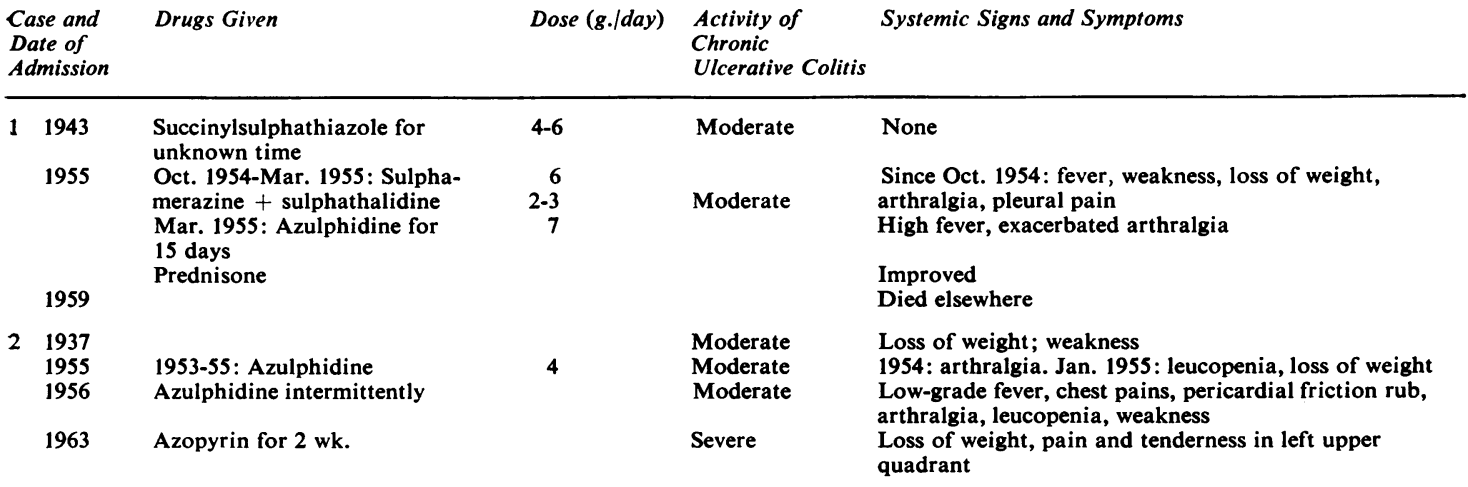

April: died 20 days after subtotal colectomy for perforated colon with abscess in left upper quadrant. Necropsy: toxic hepatitis, glomerulonephritis, right subdural haematoma.

31937

1938

1943

1955

1957

1960

41960

1961

1962
Neoprontosil for unkown time
in 1938
Azulphidine intermittently 1952-55

No sulphonamide since Oct. 1955

1958-59: Sulphasuxidine, 10 days on and 10 days off Sept. 1960: Azulphidine begun Azulphidine since Sept. 1960 Azulphidine stopped

$\begin{array}{ll}\begin{array}{l}\text { Mild } \\ \text { Mild }\end{array} & \begin{array}{l}\text { None } \\ \text { None }\end{array} \\ \begin{array}{l}\text { Mild } \\ \text { Mild to moderate Intermittent arthritis }\end{array} \\ \begin{array}{l}\text { Weostomy, arthralgia, anxiety } \\ \text { leolectomy, and } \\ \text { proctectomy }\end{array} & \text { Post-operative condition satisfactory } \\ \end{array}$

No complaints

Moderate Anaemia, cirrhosis, hepatomegaly, chronic hepatitis, palpable spleen, loss of weight

4-8 4 or more
Mild to moderate Jaundice, hepatomegaly, anaemia, weakness

Flared on stopping drug,

mild on

admission

Mar. 1962: Exploration: inoperable carcinoma of gall bladder and cirrhosis. Died first post-operative day of massive gastrointestinal haemorrhage. No necropsy.

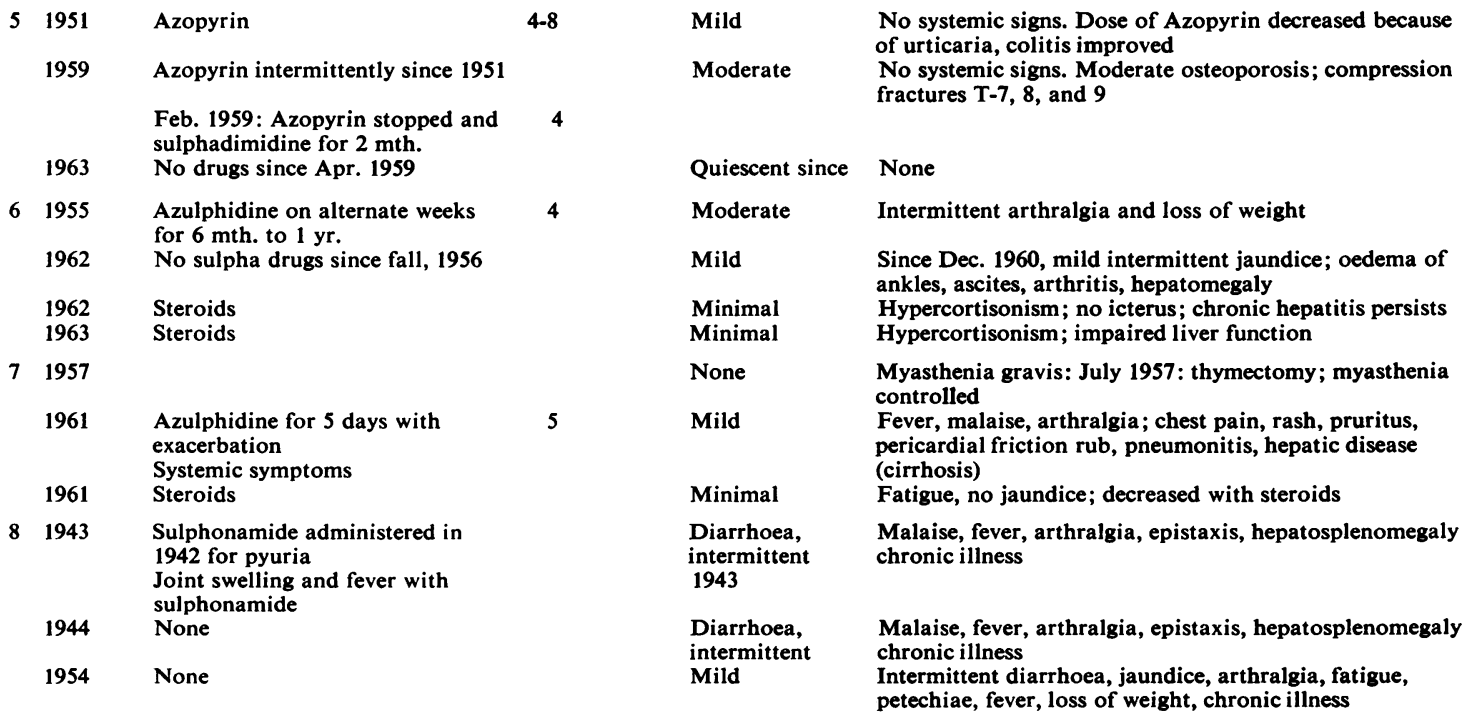

1955 Died elsewhere in coma: Aug. 1955: after transfusion reaction. No necropsy 
for 10 years with five to 20 watery stools a day containing mucus and blood. He had associated abdominal cramps, weakness, and loss of weight, but no chills or fever. Physical examination on admission was negative. Proctoscopic examination showed granular rectal mucosa that bled easily. Radiographs of the colon showed ulcerative colitis to the level of the splenic flexure.

From 1953 through 1955 exacerbations of the colitis were treated with $4 \mathrm{~g}$. of azopyrin a day. In 1954, while receiving azopyrin, the patient began to notice intermittent stiffness of the hands as well as chest pain. Use of this drug was discontinued from January 1955 until July 1955 , because of leucopenia (2,800 leucocytes). The patient returned to the Mayo Clinic in 1956 because of a relapse that was being treated with azopyrin in the same dosage. Ten days before admission, fever, malaise, and pain in the chest and right shoulder began. The chest pain was severe, constant, and unrelated to exertion.

On examination, bilateral basilar rales and pericardial friction rub were detected. Two tests were positive for L.E. cells. Other laboratory data are given in Table I. The patient was digitalized; treatment with aspirin was started, and administration of azopyrin was discontinued. The pain disappeared in a few days. On re-evaluation three months later, the colitis was quiescent, but arthralgia of the shoulder persisted. Intermittent arthralgia continued, and in 1961 bloody diarrhoea developed again. The patient returned to the Mayo Clinic in March 1963 because of intense pain of three days' duration in the left upper abdominal quadrant with extension to the left anterior part of the chest and left shoulder. It was not related to respiration. He had been taking azopyrin during the last two weeks.

Examination disclosed abdominal guarding and distension, tachycardia, but no fever. The liver was not palpable. Radiographs of the colon showed extensive chronic ulcerative colitis. L.E. cells were found on two occasions and abnormal liver function was noted (Table I). A subtotal colectomy was performed on March 25 for a perforation with abscess formation in the descending colon. Wound dehiscence required another operation on April 4. The patient did not recover consciousness, apparently because of a cerebrovascular accident. He died 10 days later.

Necropsy revealed chronic ulcerative colitis, toxic hepatitis, glomerulonephritis with bile nephrosis, subdural haematoma on the right side, and cerebral oedema on the left.

CASE 3 A 34-year-old woman was first examined at our clinic in November 1937. She gave a five-year history of loose stools containing blood and mucus. She had anal incontinence since rectal surgery for fistulae and perirectal abscesses. She was treated with codeine and a low-residue diet.

Physical examination revealed nothing of significance, but proctoscopic examination demonstrated easily bleeding, granular mucosa.

The patient returned periodically for re-examination. In 1938, she was given a sulphonamide (Neoprontosil, 3 to 5 g. per day) for an unknown period. In 1952, her active disease was limited to the rectum. She was given azopyrin which she took intermittently in a dose of 4 to 8 g. per day. In July 1955 she was having six to eight bloody stools per day accompanied by abdominal cramps. Proctoscopy revealed extensive active disease. On reinstitution of treatment with $5 \mathrm{~g}$. a day of azopyrin, chlorpheniramine (Chlor-Trimeton), and a low-residue diet, she improved rapidly and was dismissed. She was readmitted about seven days later because of painful, swollen joints. Laboratory studies (Table I) included repeatedly positive tests for L.E. cells. Treatment with azopyrin (Table II) was discontinued and the arthralgias subsided slowly. However, when treatment with azopyrin was reinstituted, the arthritis recurred. Use of azopyrin was discontinued and steroid medication was started. The arthritis subsided and the colitis remained quiescent. The L.E. cell test continued to be positive.

On examination four months later the colitis was in remission. The L.E. cells were still found. In August 1956 the L.E. cells continued to be present. The patient had a colectomy in 1957. At that time the test for L.E. cells continued to be positive. In 1960, the patient was asymptomatic and L.E. cells were not found.

CASE 4 The patient, a 62-year-old woman, came to the Mayo Clinic in September 1960. In the previous two and a half years, her stools had become loose, contained blood and mucus, and the number had increased to four to seven per day. In 1958 and 1959 she had taken sulphasuxidine intermittently. On admission, the liver was enlarged and laboratory tests showed abnormal liver function, anaemia and high sedimentation rates (Table I). A test was negative for L.E. cells. Proctoscopic and radiological examinations showed chronic ulcerative colitis that involved the rectum and entire colon. Liver biopsy revealed cirrhosis (Fig. 1). Improvement followed a programme of rest, diet, vitamins, and azopyrin (4 g. per day ) (Table II).

When the patient was seen in October 1961 she was still taking azopyrin. The colitis had decreased, but she looked ill, was pale and icteric, and had ecchymotic patches on the forearms and legs. She complained of generalized pruritus; the hepatomegaly persisted. Two tests for L.E. cells were positive. Other laboratory data may be seen in Table I. The patient was given transfusions and her previous regimen for chronic ulcerative colitis, including azopyrin, was continued.

She returned in March 1962 because of abdominal pain of one month's duration. The chronic ulcerative colitis had become exacerbated, and she had been started on corticosteroid medication. Icterus, hepatomegaly, and epigastric tenderness were present. At exploratory laparotomy, a grade 3 inoperable adenocarcinoma of the gall bladder was found. Liver biopsy revealed intrahepatic cholestasis. The patient died on the first postoperative day after a massive gastrointestinal haemorrhage. Necropsy was not performed.

CASE 5 A 58-year-old woman, when first seen at the Mayo Clinic in July 1951, gave a one-year history of bloody diarrhoea associated with abdominal cramps and weakness. Proctoscopic examination showed inflamed, 


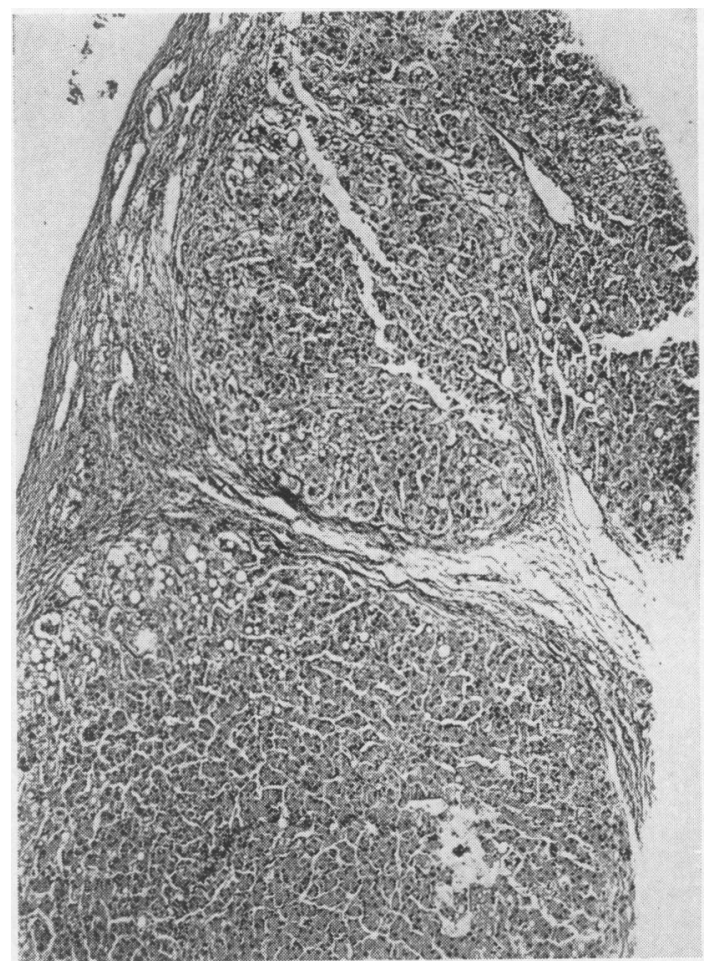

FIG. 1. Atypical cirrhosis of liver in case 4. Haematoxylin and eosin $\times 60$.

bleeding mucosa. Radiographs of the colon showed that the disease was limited to the rectum and sigmoid. A regimen of azopyrin (Table II), 4 to $8 \mathrm{~g}$. daily, belladonna, and a bland, high-protein diet was begun. Subsequently, use of azopyrin was discontinued elsewhere because of generalized urticaria. One year later treatment with azopyrin had been resumed because of another exacerbation of colitis. Again she became asymptomatic on this programme. She had an episode of angioneurotic oedema in 1955, while she was receiving $4 \mathrm{~g}$. of azopyrin a day. Treatment with azopyrin was discontinued and an antihistaminic was given. In 1956 and 1958 she had flares of the chronic ulcerative colitis that required use of azopyrin. In January, 1959, a traumatic fracture of an arm heralded a relapse of colitis. Treatment with azopyrin was begun again, but bloody diarrhoea persisted, and anaemia developed without any symptoms of systemic disease. She had active colitis and a high sedimentation rate. Two consecutive tests for L.E. cells were positive; another one showed nucleolysis and haematoxylin bodies. The azopyrin was discontinued in February, 1959 when the L.E. cell test was found to be positive and sulphadimidine was administered, $4 \mathrm{~g}$. per day, and the colitis subsided in two months. On reexamination in December, 1959, the colitis was in remission. L.E. cells were not investigated. In September 1962 she was not receiving any medication. The colitis was quiescent, and she was practically asymptomatic, and on examination essentially normal. In August, 1963, the patient was symptom free without medication. An L.E. cell preparation showed nucleolysis and nucleophagocytosis but no classic L.E. cells. She had leucopenia and an elevated sedimentation rate.

CASE 6 The patient was 11 years old when she was first seen at the Mayo Clinic in September 1955, with a 15-month history of diarrhoea with five to eight watery stools per day that contained bloody mucus. She had no cramps, fever, or chills. She had lost 20 pounds, and for the last 12 months she had intermittent arthralgia of the knees and hands.

At proctoscopic examination the rectal mucosa was granular and bled easily. Radiographs of the colon revealed chronic ulcerative colitis distal to the splenic flexure. She was dismissed with instructions to use a low-residue diet and azopyrin, 4 to $5 \mathrm{~g}$. daily on alternate weeks. She took this drug for about one year, and then remained asymptomatic on diet alone. In 1957, arthralgia of the knees and ankles developed again but improved with rest and salicylates.

In 1960, anorexia, weakness, malaise, and nausea after heavy meals began. Scleral icterus was noted and hepatitis was diagnosed. After rest in bed at home for two months she felt better; the icterus disappeared, and she returned to school. At the time she was having five loose stools a day, without blood staining.

The patient was seen again at the Mayo Clinic in April 1962, because of recurrent scleral icterus of three months' duration, easy bruising, and swelling of the ankles. Enlargement of the liver and anaemia had been found three weeks before this admission. Treatment with $8 \mathrm{mg}$. of methylprednisolone per day for arthralgia of the ankles and the left wrist caused rapid improvement.

Scleral icterus was apparent on this admission. The liver extended 4 fingerbreadths below the costal margin at the midclavicular line. There was telangiectasia of the face. Proctoscopic examination showed a rectal stricture and granular mucosa that bled easily. Radiographs showed colitis of the entire colon. Two L.E. cell tests showed rosette formation, and typical L.E. cells were seen in two other preparations. Other pertinent laboratory data for this and other admissions are given in Table I. Biopsy of the liver revealed post-necrotic cirrhosis (Fig. 2).

Because her stools were described as greasy, intestinal absorption was studied. Excretion of fat in the stools was $33.5 \mathrm{~g}$. per 24 hours. Radiological examination of the small bowel revealed normal mucosal pattern, and a peroral jejunal biopsy revealed only dilatation of lymphatic spaces in the lamina propria with normal epithelium. A low-residue diet and $8 \mathrm{mg}$. of methylprednisolone per day were prescribed.

Eight months later (December 1962), the patient was still having five stools per day with occasional blood but with no associated cramps. The tendency to bruise easily persisted, but she denied articular symptoms, and jaundice was not noted. Facies were characteristic of hypercortisonism. Only the edge of the liver was now palpable. Proctoscopic examination revealed only minimal colitis. One test for L.E. cells was negative. On 

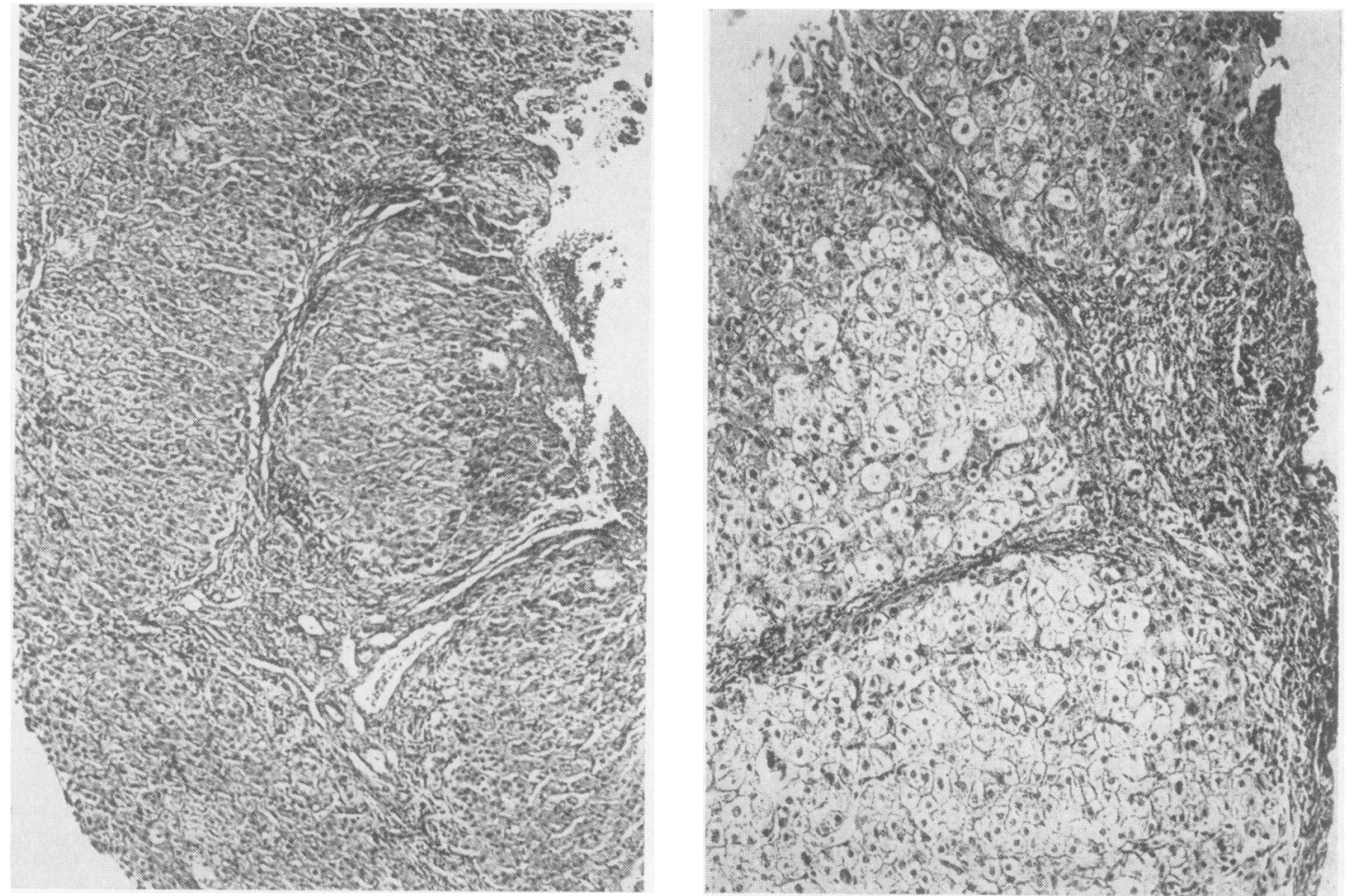

FIG. 2. Chronic hepatitis with a nodule of regeneration (postnecrotic cirrhosis) in case 6 . Haematoxylin and eosin $\times 75$.

FIG. 3. Cirrhosis in case 7. Haematoxylin and eosin $\times 125$.

discharge, the patient was taking the same dose of steroids, but she was advised to reduce it gradually. In September 1963, the patient's colitis was only mildly active. She had no specific complaints. Facies still indicated hypercortisonism.

CASE 7 The patient, a girl, was 11 years old when myasthenia gravis developed in 1957 (Alarcón-Segovia, Galbraith, Maldonado, and Howard, 1963). Thymectomy revealed thymic hyperplasia and was followed by improvement of myasthenia. In 1960, chronic ulcerative colitis developed. Five days after treatment with azopyrin was started, symptoms suggestive of systemic lupus erythematosus began and L.E. cells were found. A liver biopsy showed cirrhosis (Fig. 3). Steroid treatment was followed by simultaneous improvement of the systemic symptoms and chronic ulcerative colitis.

CASE 8 A 9-year-old girl was seen in April 1943, with a one-year history of arthritis, fever, fatigue, weakness, pallor, and epistaxis (Bartholomew et al., 1958). She received sulphanilamide because of these symptoms but felt worse with exacerbation of the arthritis. She was found to have hepatosplenomegaly, proteinuria, and slight haematuria and cylindruria. 'Peculiar rather structureless globular bodies' were observed by Dr. M. M. Hargraves in some of the cells of a bone marrow specimen. These came to be known later as L.E. cells. Other laboratory data may be seen in Table I.

The patient continued to have the same symptoms intermittently in spite of splenectomy performed elsewhere in 1944. She also gave a history of intermittent diarrhoea since 1943, but the diagnosis of chronic ulcerative colitis was not established until 1954. In addition, the patient had spells of mild jaundice from 1943 to 1954 . When she returned to our institution in 1954 fever, pallor, malnutrition, oedema of ankles, hepatomegaly, spider angiomata, petechiae, macrocytic anaemia, impaired hepatic function, L.E. cells, and ulcerative colitis involving the entire colon were found. In 1955 she died elsewhere in coma after a transfusion reaction.

\section{COMMENT}

Six of the eight patients with chronic ulcerative colitis and positive tests for L.E. cells were females. The age of the patients at onset ranged from 9 to 59 years. None of them had known familial histories of either disease. In all but one instance, the ulceraative colitis preceded the finding of L.E. cells by eight months to 29 years. One patient (case 8) had generalized symptoms and demonstrable L.E. cells a year before the onset of diarrhoea and approxi- 
mately 11 years before the established diagnosis of chronic ulcerative colitis. All eight patients had symptomatic chronic ulcerative colitis with typical proctoscopic and radiological findings. Seven of them were treated with sulphonamides because of exacerbations of colitis (Table II). In six of the seven with preceding chronic ulcerative colitis, the colitis was active when symptoms suggesting systemic lupus erythematosus appeared. The onset of symptoms suggestive of both disorders was rather abrupt in four patients (cases 1, 2, 3, and 7).

In one patient (case 5) the demonstration of L.E. cells was not accompanied by clinical manifestations suggesting systemic lupus erythematosus. The L.E. cells were found repeatedly in this patient together with a high sedimentation rate and mild anaemia. Six of the eight patients had arthralgia, and three of these had definite synovitis. Four patients had chest pain suggestive of pleuritis or pericarditis. None of the patients had erythema of the face. Mild to moderate leucopenia occurred in five patients (cases $2,4,5,7$, and 8 ).

Five of our eight patients (cases 2, 4, 6, 7, and 8) had evidence of hepatic disease. Two of them had cirrhosis, one intrahepatic cholestasis, and one had microscopic findings suggesting a more acute hepatitis. Biopsy was not done in the other patient with hepatic dysfunction. This patient and two others of the five with liver disease had hypergammaglobulinaemia.

In five of our eight patients, the symptoms attributable to systemic lupus erythematosus or the demonstration of L.E. cells in their blood occurred while they were taking azopyrin. Another patient had taken azopyrin previously but was not taking it at the time L.E. cells were found. Symptoms suggestive of systemic lupus erythematosus began while another patient was taking other sulphonamides and were noticed to increase in intensity when azopyrin was given. Our eighth patient did not take azopyrin. However, shortly after the onset of chronic ulcerative colitis she was given sulphonamides, and an exacerbation of the arthritis followed.

The association of symptoms suggestive of systemic lupus erythematosus and chronic ulcerative colitis seems to be rare. Besides the 11 well-documented cases reported in the literature (Brown et al., 1956a; Bartholomew et al., 1958; Gray et al., 1958; Larson, 1961; McEwen et al., 1962), Harvey, Shulman, Tumulty, Conley, and Schoenrich (1954) mentioned involvement of the colon in five of their 138 cases of systemic lupus erythematosus. In four of these five cases, there was arteritis with mucosal ulceration, and in the fifth there was persistent diarrhoea and bloody stools. Two of the 48 children with chronic ulcerative colitis studied by Lager- crantz, Winberg, and Zetterström (1958) had a butterfly rash. Another case of systemic lupus erythromatosus and chronic ulcerative colitis was mentioned by Boone and McKee (1956) but to our knowledge has not been reported in detail. In one of the well-documented cases reported in the literature (Brown, Shirey, and Haserick, 1956b), both diseases made a simultaneous clinical appearance, and in another one, discoid lupus erythematosus long antedated the simultaneous onset of systemic lupus erythematosus and chronic ulcerative colitis (McEwen et al., 1962). In 13 of 19 cases that have been reported, the clinical onset of chronic ulcerative colitis preceded the clinical syndrome suggesting systemic lupus erythematosus.

As mentioned earlier the small number of reported cases with the association of symptoms suggesting systemic lupus erythematosus and chronic ulcerative colitis reported may indicate that its occurrence is due to mere chance. However, one of the characteristics of the diseases that has been postulated as being related to an autoimmune mechanism is the frequent occurrence of more than one of these diseases in the same individual (Kirsner and Goldgraber, 1960; Calabresi, Thayer, and Spiro, 1961; Brearley and Spiers, 1962; MacKay and Burnet, 1963; Thayer and Spiro, 1963). Of particular interest in this regard is the occurrence of arthritis (Fernandez-Herlihy, 1959; McEwen et al., 1962) and of hepatic disease (Hargraves et al., 1948; Jones, Baggenstoss, and Bargen, 1951) in patients with chronic ulcerative colitis. The arthritis may be indistinguishable from rheumatoid spondylitis or rheumatoid arthritis (Sloan et al., 1950; Hightower et al., 1958; Fernandez-Herlihy, 1959; Wright and Watkinson, 1959; McEwen et al., 1962).

Hepatic disease associated with systemic lupus erythematosus has been recognized and studied only recently (Gray et al., 1958; Bartholomew, Cain, Baggenstoss, and Hagedorn, 1960; MacKay and Wood, 1962). The most common morphological findings in the liver have been those of hepatitis and post-necrotic cirrhosis. On the other hand, the hepatic manifestations of chronic ulcerative colitis have long been recognized. the most frequent being fatty infiltration, but intrahepatic cholestasis, hepatitis, and cirrhosis may occur also (Jones et al., 1951; Kleckner, Stauffer, Bargen, and Dockerty, 1952; Stauffer, Sauer, Dearing, and Baggenstoss, unpublished). Apparently the cirrhosis is more frequently of the post-necrotic type (Kleckner et al., 1952; Hoffbauer, McCartney, Dennis, and Karlson, 1953). In the cases reported by Gray et al. (1958), chronic ulcerative colitis coexisted with postnecrotic cirrhosis and systemic manifestations suggesting systemic lupus erythematosus. It seems 
significant that in 11 of the 19 cases collected, chronic ulcerative colitis and the clinical syndrome of systemic lupus erythematosus were associated with liver disease.

Myasthenia gravis also has been considered by some investigators (Simpson, 1960; Denney and Rose, 1961; Miller, Marshall, and White, 1962; Alarcón-Segovia et al., 1963) possibly to be related to autoimmunity. Its association with systemic lupus erythematosus has been described and its presence in one of our cases before the onset of chronic ulcerative colitis and the exacerbation of symptoms suggestive of systemic lupus erythematosus following the administration of azopyrin in this patient seem significant.

The use of sulphonamides in one form or another is a well-accepted and a widely used therapeutic measure in the treatment of chronic ulcerative colitis. Many clinicians have noted some type of intolerance to the drug in the form of nausea, vomiting, dermatitis medicamentosa and, rarely, leucopenia. These reactions are usually mild, of short duration, and probably of no great significance, clearing rapidly when the drug is discontinued. Systemic symptoms suggesting systemic lupus erythematosus following the use of sulphonamides in the treatment of chronic ulcerative colitis seem to be unusual.

Our finding of L.E. cells and the development or aggravation of systemic symptoms during treatment with sulphonamides make it possible that the role of chronic ulcerative colitis in this association is one of affording an indication for the use of drugs that unmask the lupus diathesis in certain susceptible individuals. Chronic ulcerative colitis, particularly when accompanied by liver disease, may in itself be a clue to the existence of that susceptibility (lupus diathesis). That drug therapy, including sulphonamides and particularly hydralazine, may elicit the clinical manifestations of systemic lupus erythematosus in the susceptible individual is well documented in the literature (Gold, 1951; Honey, 1956; Domz, McNamara, and Holzapfel, 1959; Comens, 1961 ; Rallison, O'Brien, and Good, 1961 ; Alarcón-Segovia, Worthington, Ward, and Wakim, 1965). On the other hand, drug reactions are so frequent in patients with systemic lupus erythromatosus that they are often considered to have significant diagnostic importance. Seven of our patients with chronic ulcerative colitis experienced the onset or an exacerbation of symptoms compatible with systemic lupus erythematosus while sulphonamides were being administered.

It is not our intention to suggest that chronic ulcerative colitis is a form of systemic lupus erythematosus, but it is possible that the two are somehow related. The possibility that some individuals with chronic ulcerative colitis under certain circumstances may present a clinical picture that resembles systemic lupus erythematosus must now be recognized and studied more extensively in the future. The further study of L.E. cells and antinuclear factors in patients with chronic ulcerative colitis, and particularly in those with systemic manifestations, is desirable in order to achieve better understanding of both diseases and their possible interrelationship.

\section{SUMMARY AND CONCLUSIONS}

A search for cases in which clinical syndromes suggestive of systemic lupus erythematosus was associated with chronic ulcerative colitis disclosed 11 cases in the literature. Eight additional cases from the Mayo Clinic are reported. In seven of our eight patients the colitis preceded the onset of symptoms suggestive of systemic lupus erythematosus. One patient had been considered to have systemic lupus erythematosus for several years before the onset of chronic ulcerative colitis.

All eight patients had received some sulphonamide preparation at some time for their illness. In seven, the onset or an exacerbation of the manifestations attributable to systemic lupus erythematosus occurred while the patient was taking sulphonamides. In five, L.E. cells were demonstrable at this time.

Eleven of the 19 patients in the series reported in the literature, including five of the eight in the present group, had associated hepatic disease. The overall clinical syndrome suggests that these patients with chronic ulcerative colitis may have an underlying lupus diathesis which is unmasked by sulphonamides.

\section{REFERENCES}

Alarcón-Segovia, D., Galbraith, R. F., Maldonado, J. E., and Howard, F. M., Jr. (1963). Systemic lupus erythematosus following thymectomy for myasthenia gravis: report of two cases. Lancet, 2, 662-665.

_-, Worthington, J. W., Ward, L. E., and Wakim, K. G. (1965). Lupus diathesis and the hydralazine syndrome. New Engl. J. Med In the press.

Bartholomew, L. G., Cain, J. C., Baggenstoss, A. H., and Hagedorn, A. B. (1960). Further observations on hepatitis and cirrhosis in young women with positive clot tests for lupus erythematosus. Gastroenterology, 39, 730-736.

—, Hagedorn, A. B., Cain, J. C., and Baggenstoss, A. H. (1958). Hepatitis and cirrhosis in women with positive clot tests for lupus erythematosus. New Engl. J. Med., 259, 947-956.

Boone, J., and McKee, J. A. (1956). Personal communication. Quoted by Brown, C. H., et al. (1956a, 1956b).

Brearley, K. S., and Spiers, A. S. D. (1962). Autoimmune disease of the thyroid and colon, with a report of a case of chronic ulcerative colitis in association with Hashimoto's disease and penicillin allergy. Med. J. Aust., 1, 789-795.

Brown, C. H., Haserick, J. R., and Shirey, E. K. (1956a). Chronic ulcerative colitis with systemic lupus erythematosus: report of a case. Cleveland Clin. Quart., 23, 43-46. 
Brown, C. H., Shirey, E. K., and Haserick, J. R. (1956b). Gastrointestinal manifestations of systemic lupus erythematosus. Gastroenterology, 31, 649-666.

Calabresi, P., Thayer, W. R., Jr., and Spiro, H. M. (1961). Demonstration of circulating antinuclear globulins in ulcerative colitis. J. clin. Invest., 40, 2126-2133.

Comens, P. (1961). In Inflammation and Diseases of Connective Tissue. A Hahnemann Symposium, edited by L. C. Mills, and J. H. Moyer, pp. 190-200. Saunders, Philadelphia.

Denney, D., and Rose, R. L. (1961). Myasthenia gravis followed by systemic lupus erythematosus: a case report. Neurology (Minneap.), 11, 710-713.

Domz, C. A., McNamara, D. H., and Holzapfel, H. F. (1959). Tetracycline provocation in lupus erythematosus. Ann. intern. Med., 50, 1217-1226.

Fernandez-Herlihy, L. (1959). The articular manifestations of chronic ulcerative colitis: an analysis of 555 cases. New Engl. J. Med., 261, 259-263.

Gold, S. (1951). Role of sulphonamides and penicillin in the pathogenesis of systemic lupus erythematosus. Lancet, 1, 268-272.

Good, R. A., and Condie, R. M. (1961). Reflections of the nature and interrelationships of certain hypersensitivity reactions in man. Gastroenterology, 40, 344-355.

Gray, N., Mackay, I. R., Taft, L. I., Weiden, S., and Wood, I. J. (1958). Hepatitis, colitis and lupus manifestations. Amer. J. dig. Dis., 3, 481-491.

Hargraves, M. M. (1954). Systemic lupus erythematosus and L.E. cell phenomenon. Postgrad. Med., 16, 163-174.

—, Richmond, H., and Morton, R. (1948). Presentation of two bone marrow elements: the "tart" cell and the "L.E." cell. Proc. Mayo Clin., 23, 25-28.

Harvey, A. M., Shulman, L. E., Tumulty, P. A., Conley, C. L., and Schoenrich, E. H. (1954). Systemic lupus erythematosus: review of the literature and clinical analysis of 138 cases. Medicine (Baltimore), 33, 291-437.

Hightower, N. C., Jr., Broders, A. C., Jr., Haines, R. D., McKenney, J. F., and Sommer, A. W. (1958). Chronic ulcerative colitis. II. Complications. Amer. J. dig. Dis., 3, 861-876.

Hoff bauer, F. W., McCartney, J. S., Dennis, C., and Karlson, K. (1953). The relationship of chronic ulcerative colitis and cirrhosis. Ann. intern. Med., 39, 267-284.

Honey, M. (1956). Systemic lupus erythematosus presenting with sulphonamide hypersensitivity reaction. Brit. med. J., 1, $1272-1275$.

Jones, G. W., Baggenstoss, A. H., and Bargen, J. B. (1951). Hepatic lesions and dysfunction associated with chronic ulcerative colitis. Amer. J. med. Sci., 221, 279-286.
Kirsner, J. B., and Goldgraber, M. B. (1960). Hypersensitivity, autoimmunity, and the digestive tract. Gastroenterology, 38, 536-562.

Kleckner, M. S., Jr., Stauffer, M. H., Bargen, J. A., and Dockerty, M. B. (1952). Hepatic lesions in the living patient with chronic ulcerative colitis as demonstrated by needle biopsy. Ibid., 22, 13-33.

Kraft, S. C., Bregman, E., and Kirsner, J. B. (1962). Criteria for evaluating autoimmune phenomena in ulcerative colitis. Ibid., $43,330-336$.

Lagercrantz, R., Winberg, J., and Zetterström, R. (1958). Extracolonic manifestations in chronic ulcerative colitis. Acta paediat. (Uppsala.), 47, 675-687.

Larson, D. L. (1961). Systemic Lupus Erythematosus, Little, Brown, Boston.

MacKay, I. R., and Burnet, N. F. (1963). Autoimmune Diseases: Pathogenesis, Chemistry, and Therapy. Thomas, Springfield.

cases with other types of chronic liver disease. Quart. J. Med., 31, 485-507.

McEwen, C., Lingg, C., Kirsner, J. B., and Spencer, J. A. (1962). Arthritis accompanying ulcerative colitis. Amer. J. Med., 33, 923-941.

Miller, J. F. A. P., Marshall, A. H. E., and White, R. G. (1962). In Advances in Immunology, edited by $\mathrm{W}$. $\mathrm{H}$. Taliaferro, and J. H. Humphrey, vol. 2, pp. 111-162. Academic Press, New York.

Rallison, M. L., O'Brien, J., and Good, R. A. (1961). Severe reactions to long-acting sulfonamides: erythema multiforme exudativum and lupus erythematosus following administration of sulphamethoxypyridazine and sulfadimethoxine. Pediatrics, 28, 908-917.

Simpson, J. A. (1960). Myasthenia gravis: a new hypothesis. Scot. med. J., 5, 419-436.

Sloan, W. P., Jr., Bargen, J. A., and Gage, R. P. (1950). Life histories of patients with chronic ulcerative colitis: a review of 2,000 cases. Gastroenterology, 16, 25-38.

Stauffer, M. H., Sauer, W. G., Dearing, W. H., and Bagenstoss, A. H. Unpublished data.

Thayer, W. R., Jr., and Spiro, H. M. (1963). Protein abnormalities in ulcerative colitis patients and their families. Gastroenterology, 44, 444-447.

Wright, V., and Watkinson, G. (1959). The arthritis of ulcerative colitis. Medicine (Baltimore), 38, 243-259.

Zimmer, F. E., and Hargraves, M. M. (1952). The effect of blood coagulation on L.E. cell formation. Proc. Mayo Clin., 27, 424-430. 